ELT Echo : The Journal of English Language Teaching in Foreign Language Context

journal homepage: https://syekhnurjati.ac.id/jurnal/index.php/eltecho

\title{
IMPLEMENTING GOOGLE CLASSROOM-BASED COGNITIVE STRATEGY FOR ENGLISH FOR SPECIFIC PURPOSES
}

\author{
Rizky Eka Prasetya \\ Akademi Sekretari Budi Luhur, Indonesia \\ *Corresponding author: Indonesia. E-mail addresses: rizky.ekaprasetya@budiluhur.ac.id \\ article info abstrat \\ Article history: \\ Received: 10 March 2021 \\ Received in revised form: 25 June \\ 2021 \\ Accepted: 28 June 2021 \\ Available online: 29 June 2021 \\ Keywords: \\ Google Classroom \\ Cognitive Strategy \\ Teaching English \\ Higher Education

\begin{abstract}
Pedagogical language has shifted dramatically and significantly in these recent pandemic eras. Lectures should be adjusted from the face-to-face teaching style into the online teaching environment. The study's purposes are to explore and investigate the availability of cognitive strategy to teach English in Google Classroom circumstances. This study employed the exploratory sequential mixed methods approach involving thirty-seven English lecturer in its mixed-method data collection stages. The study found the adaptability and acceptance of google classroom-feature in terms of collaborative strategic reading, peer-assisted learning strategies, transactional strategies instruction, and conceptoriented reading instruction. Google Classroom is compatible with an English online pedagogy setting for developing and enhancing English teaching and learning. English Lecturers would have the opportunity to apply and adjust the cognitive strategy for teaching procedure.
\end{abstract}

\section{INTRODUCTION}

The Indonesian government was compelled to replace traditional classes and educational activities with remote learning due to the global Covid-19 pandemic. This transformation encourages all schools and Higher Education Institutions to involve technology in the pedagogical process. Qazi et al. (2020) remarked that a comprehensive online education needs a scheme for developing, for instance, audio and video contents relevant to learning elements into selective learning materials. Computerized technology and pandemic has encouraged and strengthened Information and Communication Technology (ICT) in education. New normal has brought and reshaped the integration of technology into the pedagogical process, particularly language learning and teaching (Chen et al. 2020). The Indonesian government implements distance learning (e-learning) as the solution to the continuation of the education process at all levels.

This new electronic learning ecosystem needs to be readjusted and reorganized by every Indonesian educational process participant, including lecturers and language learners. Adnan and Anwar (2020) asserted that language learning adaptability to technology had developed 
several decades ago. Many experts utilize technology to create a well-prepared material and comfortable environment and to encourage language learners to interact with their peers and lecturers. Contrarily, Atmojo and Nugroho (2020) concluded that the condition was different in Indonesia. The vast geographical country creates a unique challenge to apply and adopt the technology for all Indonesia areas. Integrating and implementing technology evenly in the Indonesian education context is challenging. Several obstacles and challenges must be overcome to obtain the advantages. According to Chinmi et al. (2020), "infrastructure and cultural issues are critical, particularly issues with internet connectivity constraints, a lack of technological experience, a reluctance to adjust to the learning conditions, and little acknowledgment of performing effective eLearning."

All education stakeholders should encourage the process to effectively design and collaborate the integration of ICT into English Language Teaching (ELT). Troussas et al. (2019) affirmed that Computer-Assisted Language Learning (CALL) made significant language process education improvements. The similarity to the conception of social constructivism is that the ICT boosts language learners to participate in their learning activities and simultaneously develop their previous knowledge. Additionally, Santos et al. (2016) explained that it helps establish a fundamental framework for English lecturers' application and performance. Language Learners developed freedom in their learning and improve their education's efficiency, which is also linked to learner independence. Chapelle and Voss (2016) established that advanced technology in English language teaching has accordingly grown needed. They adjusted English language education and provided lecturers with the classroom methodically and unconventionally. The Internet presents obvious, quick, and implicitly unrestricted access to web applications and auxiliary programs so that content can facilitate English pedagogy.

Izenstark and Leahy (2015) asserted that Google Classroom implies the educational innovations contributed to Google Apps for Education (GAFE). Kumar et al. (2020) affirmed that the system is a learning program allowing class production in the electronic environment. It can assign tasks, offer various testing, and evaluate accumulated assignments. This type of learning system might be accessed without charge by the educators. Sholah (2020) asserted that learning English within Google classroom delivers it efficiently in the pedagogical process, and learning applications based on Google classroom are quite serviceable in encouraging current experience and stimulating language learners. Google Classroom has 
effective characteristics such as interactive learning, learner engagement, completion of learning . Cyberlearning is equal to the online or virtual classroom that enables members to interact with participants, observe presentations or videotape, and be involved with electronic resources (Abazi-Bexheti et al., 2018). Additionally, Lai (2015) explained that the web-based learning system is considered the best education platform to generate lecturers' pedagogical instruction. It included flexible characteristics that provide an excellent environment for asynchronous and synchronous learning and teaching, and the advanced ecosystem helps lecturers effectively generate resources, manage the pedagogical process, and enhance interaction.

The technology adaptability of lecturers needs to be improved because their role has changed drastically in the eLearning ecosystem. Azhar and Iqbal (2018) concluded that the institution must understand instructional technology's role as learning support and build content and establish processes. Ahmadi and Reza (2018) affirmed that English Lecturers must understand technology's capabilities to promote learning and improve their effectiveness. English lecturers recommend having a sense of adaptability to the teaching material and style inside the system, particularly Google Classroom. Moreover, Gilakjani (2017) concluded that the teaching approach and method could shift into more interaction with language learners. The condition could happen poorly if all the pedagogical system members have lack information related to it. In online language teaching, lecturers have acknowledged the distinctions between face-to-face teaching and electronic classes. There appears to be a light mutual endeavor to recognize and investigate the latest methods and abilities that online language lecturers seriously need. Their preparation or professional improvement occasionally reaches behind technological and software-particular experiences (Regan et al., 2019).

Cognitive strategies, which contextually to language learning, are defined as mental methods or systems fulfilling cognitive purposes like solving problems, investigating an assessment, or understanding the text's meaning (Di Carlo. 2017). Cognitive strategies, which contextually to language learning, are defined as mental methods or systems fulfilling cognitive purposes like solving problems, investigating an assessment, or understanding the text's meaning. Kashefian-Naeeini and Maarof (2016) claimed that numerous types of strategies are applied for complex cognitive outcomes. Gilakjani and Sabouri (2016) affirmed that the strategies involved in language approaches concentrate on cultural, discourse, social, 
communicational, pragmatic, grammatical, semantic, stylistic, and rhetorical. On the other hand, cognitive strategies became the number of strategies for various tasks in different knowledge domains. Strategies are applied for examining and resolving problems, and it generates by memorizing a sequence of experiences (Ashman and Conway. 2017). Additionally, the process of planning, drafting, reviewing, and revising happens with a critical expository essay. Gabriele et al. (2017) stated that the notion also centered on the strategy of self-questioning, forming imaginative illustrative visions, stimulating previous information, reading puzzling parts of texts, divining or reviewing a topic.

There have been few observational investigations on Google Classroom-based applications' capabilities and adaptability to facilitate Higher Educations' language teaching strategy. Implementing online learning activities could probably promote the improvement of essential and valuable pedagogical knowledge. Nevertheless, implementing and presenting face-to-face learning circumstances cannot transpose effectively to an electronic-based Internet ecosystem. Previous studies were proving the opportunity and advantage of teaching cognitive strategies to language learners. The study's purpose was to investigate whether English lecturers could implement specific guidance to learners. These explanations increased language learners' awareness of the need to practice strategies and how to utilize them, and whether specific information increased learners' achievement. This study referred to the research question as 1) what feature does cognitive strategy implement in Google Classroombased? 2) How can cognitive strategy adapt to the google classroom-based?

\section{METHOD}

This study employed the mixed-method design with exploratory sequential design, which investigates the quantitative and qualitative data from lecturers' experience in implementing English learning with cognitive strategy through Google Classroom. This method is intentionally integrating or connecting quantitative and qualitative procedures as elements of the study. Applying these approaches might have occurred at various investigation processes and present a possibility-alternative viewpoint in a study.

The thirty-seven participants and respondents were involved in this study, and they have typically had the same experience conducting teaching in the google classroom ecosystem. The condition has shifted from traditional pedagogical classroom to electronic system because of the pandemic. They had internal training for their institution for 
implementing e-Learning and completed the first term in fully online learning. The participants' complete demographic is in table 1.

Table 1. The General characteristics of Participants

\begin{tabular}{lccc}
\hline \multicolumn{1}{c}{ Items } & Element & $\begin{array}{c}\text { Total of } \\
\text { Participants (N) }\end{array}$ & $\begin{array}{c}\text { Total in } \\
\text { Percentage (\%) }\end{array}$ \\
\hline \multirow{2}{*}{ Sex } & Male & 13 & $38 \%$ \\
\hline \multirow{2}{*}{ Age } & Female & 24 & $70 \%$ \\
\hline \multirow{2}{*}{$\begin{array}{l}\text { Background Teaching in } \\
\text { Higher Education }\end{array}$} & $>$ 40 Old Years & 25 & $67 \%$ \\
\cline { 2 - 4 } & $<40$ Old Years & 12 & $32 \%$ \\
\hline \multirow{2}{*}{ Academic Degree } & $<10$ Years & 16 & $47 \%$ \\
\hline & Master Degree & 18 & $52 \%$ \\
\hline
\end{tabular}

Data on cognitive strategy implementation details were generated online by using the Google Forms questionnaire. The questionnaire covered A1) collaborative strategic reading, A2) peer-assisted learning strategies, A3) transactional strategies instruction, and A4) concept-oriented reading instruction. In addition, the open-ended interview was carried out to obtain a comprehensive perspective of the lecturers on the cognitive strategy and their experience in its implementation. The interpretation and analysis of the descriptive data from the open ended interview and statistical data from the questionnaire were then carried out.

\section{FINDINGS}

\section{The Collaborative Strategic Reading}

Collaborative strategic reading implied a teaching strategy or technique to develop language learners' proficiency in reading understanding. The principle was a discussion activity. Therefore, it was arranged into several groups, and then individually, the student has a distinct function in the study.

Table 2. The Collaborative Strategic Reading Result

\begin{tabular}{|c|c|c|c|c|}
\hline $\begin{array}{c}\text { Instructional Collaborative Strategic } \\
\text { Reading }\end{array}$ & $\mathbf{N}(\%)$ & $\bar{x}($ Mean $)$ & Median & $\begin{array}{c}\text { S.D } \\
\text { (Standard } \\
\text { Deviation) }\end{array}$ \\
\hline $\begin{array}{l}\text { Inform the student of the appropriate } \\
\text { learning strategies }\end{array}$ & $37(100 \%)$ & 9.25 & 8 & 3.9 \\
\hline
\end{tabular}




\begin{tabular}{|c|c|c|c|c|}
\hline Introduce the text and choose the topic & $37(100 \%)$ & 9.25 & 8.5 & 2.6 \\
\hline Guide the learners to identify the text & $37(100 \%)$ & 9.25 & 10 & 2.2 \\
\hline $\begin{array}{l}\text { Ask learners based on the group to find } \\
\text { difficult vocabulary. If they understand } \\
\text { (click), and if they do not understand } \\
\text { (clunk) }\end{array}$ & $37(100 \%)$ & 9.25 & 8.5 & 1.8 \\
\hline $\begin{array}{l}\text { Identify the essential idea each } \\
\text { paragraph }\end{array}$ & $37(100 \%)$ & 9.25 & 10.5 & 6.8 \\
\hline $\begin{array}{l}\text { The purposes are to enhance students' } \\
\text { knowledge, comprehension, and } \\
\text { remembrance of what they have read. }\end{array}$ & $37(100 \%)$ & 9.25 & 7.5 & 6.0 \\
\hline $\begin{array}{l}\text { Review clunks or shares some review } \\
\text { ideas. }\end{array}$ & $36(97 \%)$ & 9 & 9.5 & 3.1 \\
\hline $\begin{array}{l}\text { Assign student for group work or } \\
\text { discussion }\end{array}$ & $35(94 \%)$ & 8.75 & 6.5 & 6.3 \\
\hline Comprehend each paragraph & $35(94 \%)$ & 8.75 & 8.5 & 0.9 \\
\hline Asks them to discuss the result together, & $35(94 \%)$ & 8.75 & 7.5 & 5.1 \\
\hline $\begin{array}{l}\text { Assist learners in previewing the clues. } \\
\text { Provide example text, picture, charts, or } \\
\text { graphs }\end{array}$ & $33(89 \%)$ & 8.25 & 7 & 5.7 \\
\hline $\begin{array}{l}\text { Offer the students some reading test } \\
\text { based on the text they have read. }\end{array}$ & $32(86 \%)$ & 8 & 6.5 & 4.9 \\
\hline
\end{tabular}

Table 1 has shown that the mean $(\bar{x})$ number for the first item regarding guide the learners to identify the text is 3.58 with a 2.2 point as the standard deviation. This score means that this item is the most recognized detail by the participants. The further analysis focused on the next item in the highest mean of 9.25, then 2.6, and 3.9 standard deviation score. The indicators come up with minor variation because the standard deviation result is less than the mean result. On the other hand, the distinguished mean score and standard deviation could be interpreted as adequate data. The item offered to the students some reading test based on the text they have read found less response on 32 from $86 \%$. The variation items are fair because the standard deviation scores less than the median and mean.

"The reading ability concentrated on our syllabus. It means the expectation of learners to gain and improve their vocabulary. our language lecturers expected to present the text, select it by the learners' preferences, and examine each main paragraph as the meaning and concept in all text." (Respondent 13). 
Collaborative Strategic Reading (CSR) provided cognitive strategy direction to accommodate learners to understand texts under several areas. Additionally, this strategy supports learning disabilities and gives language learners possibilities to study collaboratively in peer-mediated electronics environments. This strategy was an integrated teaching reading strategy employed to encourage the language learners' knowledge of the text while studying cooperatively. Various implementation on the strategy, the primary purposes language lecturers assisted previewing by remembering them to apply all the visual clues in the text, include an image, chart, graphs, and others. A fundamental characteristic of CSR was learner interaction in particular study groups. All team members were assigned a different role, and they have a chance to practice and study each one.

\section{Peer-Assisted Learning Strategies}

Peer-assisted learning strategies referred to the approach or procedure to support language learning that is practiced as a complement to current language pedagogical studies, where learners happen to have more experienced instructors and guide learners to access language learning.

Table 3. Peer-Assisted Learning Strategies Result

\begin{tabular}{|c|c|c|c|c|}
\hline $\begin{array}{l}\text { Instructional Peer-Assisted } \\
\text { Learning Strategies }\end{array}$ & $\mathbf{N}(\%)$ & $\bar{x}($ Mean $)$ & Median & $\begin{array}{c}\text { S.D } \\
\text { (Standard } \\
\text { Deviation) }\end{array}$ \\
\hline $\begin{array}{l}\text { increase student motivation and } \\
\text { make them delighted and } \\
\text { comfortable }\end{array}$ & $36(97 \%)$ & 9 & 9.5 & 3.1 \\
\hline $\begin{array}{l}\text { Provide an opportunity for each } \\
\text { of them to take turns being the } \\
\text { group leader }\end{array}$ & $36(97 \%)$ & 9 & 9 & 3.3 \\
\hline $\begin{array}{l}\text { Improve their reading abilities } \\
\text { by blending reading and writing } \\
\text { activities. }\end{array}$ & $36(97 \%)$ & 9 & 9.5 & 3.9 \\
\hline $\begin{array}{l}\text { Present time and space for } \\
\text { learners to decide on books and } \\
\text { material of their preferences }\end{array}$ & $36(97 \%)$ & 9 & 8.5 & 2.1 \\
\hline $\begin{array}{l}\text { Encourage learners to generate } \\
\text { and develop a positive } \\
\text { classroom approach with shared } \\
\text { purposes, good strength, and } \\
\text { teamwork knowledge. }\end{array}$ & $35(94 \%)$ & 8.75 & 6.5 & 6.3 \\
\hline
\end{tabular}


practice peer-assisted learning strategies reading sessions could entail pairing or grouping students

Present learners available for questions or assistance.

$33(89 \%)$

8.25

$31(83 \%)$
7.75
8.5

4.9

Table 3 demonstrates that the application of cognitive strategy, particularly peerassisted learning strategies' total mean score, is highest $(\overline{\mathrm{x}}=9)$, and the median is 9.5 . it covered the aspect of Improve their reading abilities by blending reading and writing activities. The other highest result on mean and median included increases student motivation, creates them seem delighted and comfortable and acknowledges them to take turns being the group leader. These indicators explained that lecturers have an active strategy to implement the peer-assisted learning strategies in google classroom to enhance cognitive strategy. The lowest $\overline{\mathrm{x}}$ score with 7.75 and 8 as the median score covered with Present learners available for questions or assistance

"We expect to have proper communication in an electronic class environment. Thus, we recommended using google classroom based on our institution programs. In reading English, we collaborate all the electronic resources for learners and choose the best and interesting for them to discuss in google meet as a video conference. I also give a spare time for them to confirm and ask if there is something that might be difficult for them to read" (Respondent 19)

Peer-Assisted Learning Strategy (PALS) was a teaching English pedagogy procedure concentrated in reading subject's practice. The lecturers distributed the language learners into two groups or more, and they matched employing a ranking method. PALS developed learners' reading understanding because it centred on particular learner inadequacies relatively than a lecturer-conducted activity that probably addresses several language learners' needs. In addition, this strategy suggested all the learners complete thoroughly, improved their possibility to read, trained their necessary vocabulary abilities, implemented actual and productive peer communication, organized the possibility for below-functioning learners to understand an essential function in an evaluated activity, urged learners to do adequately in reading, supported lecturers receive academic variety environment 


\section{Transactional Strategies Instruction}

Transactional strategies instruction (TSI) indicated the method employed to develop reading understanding strategies. TSI practised in combination with some multi-text. The strategy accomplished text with nonfiction or fiction, essays, online manuscripts, and printed books. It is essential to perceive that TSI was appropriately applicable if taught in association with an English subject.

Table 4 Transactional strategies instruction Result

\begin{tabular}{|c|c|c|c|c|}
\hline $\begin{array}{l}\text { Instructional Transactional } \\
\text { strategies instruction }\end{array}$ & $\mathbf{N}(\%)$ & $\bar{x}($ Mean $)$ & Median & $\begin{array}{c}\text { S.D } \\
\text { (Standard } \\
\text { Deviation) }\end{array}$ \\
\hline $\begin{array}{l}\text { Visualize the text, or monitor } \\
\text { their comprehension at } \\
\text { predetermined points. }\end{array}$ & $37(100 \%)$ & 9.25 & 10.5 & 4.5 \\
\hline $\begin{array}{l}\text { Record predictions on the } \\
\text { teaching graphic organizer and } \\
\text { questions to guide their reading } \\
\text { of the big book. }\end{array}$ & $33(89 \%)$ & 8.25 & 10 & 5.9 \\
\hline $\begin{array}{l}\text { Stop to review predictions for } \\
\text { corrections, }\end{array}$ & $37(100 \%)$ & 9.25 & 10 & 6.3 \\
\hline $\begin{array}{l}\text { Check predictions using the } \\
\text { graphic organizer. }\end{array}$ & $37(100 \%)$ & 9.25 & 10 & 4.8 \\
\hline $\begin{array}{l}\text { Summarize and then guide the } \\
\text { students in creating a summary. }\end{array}$ & $37(100 \%)$ & 9.25 & 10 & 3.8 \\
\hline $\begin{array}{l}\text { Examine the text is arranged, } \\
\text { preview the text's title, models, } \\
\text { specifications, or tables. }\end{array}$ & $36(97 \%)$ & 9 & 9.5 & 3.9 \\
\hline $\begin{array}{l}\text { Read the text together: teacher } \\
\text { read-aloud or choral reading. }\end{array}$ & $37(100 \%)$ & 9.25 & 9.5 & 2.5 \\
\hline $\begin{array}{l}\text { Reflect on the usefulness of the } \\
\text { strategies. }\end{array}$ & $37(100 \%)$ & 9.25 & 9.5 & 3.5 \\
\hline $\begin{array}{l}\text { Stimulate students' experience } \\
\text { knowledge concerning subject } \\
\text { or issue practising the graphic } \\
\text { organizer }\end{array}$ & $34(91 \%)$ & 8.5 & 9 & 3.4 \\
\hline $\begin{array}{l}\text { Invite students to ask and } \\
\text { discuss their answers } \\
\text { questions. }\end{array}$ & $37(100 \%)$ & 9.25 & 9 & 5.1 \\
\hline $\begin{array}{l}\text { Devise concluding points in the } \\
\text { text for practising } \\
\text { comprehension strategies and } \\
\text { reviewing the text. }\end{array}$ & $37(100 \%)$ & 9.25 & 8.5 & 1.8 \\
\hline $\begin{array}{l}\text { Predicti and invite students to } \\
\text { predict. }\end{array}$ & $32(86 \%)$ & 8 & 8.5 & 6.1 \\
\hline
\end{tabular}

Observing Table 2 clarified that the lecturers' adaptability on the Transactional strategies' instruction approach in the cognitive strategies has the highest median score as 
10.5 with a mean of 9.25. the item of visualize the text or monitor their comprehension at predetermined points would have been ideal variation because the standard deviation (4.5) is less than the mean and median. Comparatively, the item predicting and inviting language learners to predict had the lowest median (8) and mean (8.5) with the standard deviation of 6.1. The lowest respondent acknowledged this item. The first assumption was that they had a limited situation to comply with the activity. The lowest median covered Device's concluding points in the text for practising comprehension strategies, reviewing the text, and Predicting and inviting students to predict. The comparison through these items with the standard deviation from 1.8 to 6.8 . These illustrations presented the description of many lecturers reluctant to apply to this instructional because it was challenging to implement it in Google Classroom

"The reading subject's purpose is to have a better vocabulary in English based on various contexts. Electronic learning might be possible to implement. In my class, I present a visual graphic to encourage our reading motivation. We can discuss something from the text and examine what vocabulary the learners did not know before. This activity was effective in encouraging them to read more." (Respondent 01)

Transactional Strategies Instruction (TSI) requires language lecturers to represent their understanding procedures to confirm their versatility in complex, insightful circumstances. Lecturers handled a reflective discussion regarding a general text to the learners, who are also supposed to demonstrate their strategies and deliver their thoughtful answers to the text's content. TSI aimed to create learners who independently utilize the understanding approaches as they read some text, and this goal is for Complete learners.

\section{Concept-Oriented Reading Instruction}

This Concept-Oriented Reading Instruction (CORI) strategy encouraged learners to confront reading understanding applying several levels as an instructional procedure. These impressions are observing text arrangements, affecting, and thought-organizing. Every level of this strategy enhanced the pedagogical language process's capability to develop its reading knowledge. 
Table 5 Concept-Oriented Reading Instruction Result

\begin{tabular}{|c|c|c|c|c|}
\hline $\begin{array}{c}\text { Instructional Concept-Oriented } \\
\text { Reading Instruction }\end{array}$ & $\mathbf{N}(\%)$ & $\bar{x}($ Mean $)$ & Median & $\begin{array}{l}\text { S.D (Standard } \\
\text { Deviation) }\end{array}$ \\
\hline Reviewing the materials' topics & $36(97 \%)$ & 9 & 10 & 6.3 \\
\hline $\begin{array}{l}\text { Collaborate with learners to } \\
\text { understand what these topics are } \\
\text { meaning. }\end{array}$ & $36(97 \%)$ & 9 & 10 & 5.2 \\
\hline $\begin{array}{l}\text { measuring and recording readings } \\
\text { at the weather station outside } \\
\text { school }\end{array}$ & $35(94 \%)$ & 8.75 & 10 & 4.9 \\
\hline $\begin{array}{l}\text { Read lots of books is valuable for } \\
\text { comprehension. CORI fosters } \\
\text { high amounts of reading in order } \\
\text { to build comprehension. }\end{array}$ & $36(97 \%)$ & 9 & 9 & 3.3 \\
\hline $\begin{array}{l}\text { Share learners understand with } \\
\text { others in their class through } \\
\text { presentations activities }\end{array}$ & $34(91 \%)$ & 8.5 & 9 & 3.4 \\
\hline $\begin{array}{l}\text { Delve deeply into investigating } \\
\text { their scientific topic via books. }\end{array}$ & $34(91 \%)$ & 8.5 & 8.5 & 2.8 \\
\hline $\begin{array}{l}\text { Understand the topics through } \\
\text { students reading activities }\end{array}$ & $37(100 \%)$ & 9.25 & 7.5 & 4.5 \\
\hline $\begin{array}{l}\text { Invites Students to observe audio- } \\
\text { visual material. }\end{array}$ & $34(91 \%)$ & 8.5 & 7.5 & 5.0 \\
\hline $\begin{array}{l}\text { Ask learners questions about the } \\
\text { meaning and content of these } \\
\text { audio-visual materials. }\end{array}$ & $32(86 \%)$ & 8 & 7.5 & 2.9 \\
\hline
\end{tabular}

Table 5 explained that the mean $(\overline{\mathrm{x}})$ number for the highest median item reviewing the materials' topics is 9 , with a 6.3 point as a standard deviation. The other indications were respondent likely to apply to collaborate with learners to understand what these topics were meaning, measuring and recording readings at the weather station outside school read lots of books are valuable for comprehension, CORI fostered high amounts of reading in order to build comprehension, and share learners understand with others in their class through presentations activities. Observing from the three items with the result response above 95\%, this probably assumed that google classrooms established adaptability to the electronic class's fourth activities. However, delving deeply into investigating their scientific topic via books, understanding the topics through students reading activities, invite students to observe audiovisual material, and asking learners' questions about the meaning and content from these audio-visual materials were partially applied in the google classroom context with a standard deviation range from $2.9-5.0$

“The university's student learns English to focus and gain lots of information based on the current topic in real life. Electronic resources could potentially accommodate 
those activities. However, the implementation could vary from one language learner, so electronic learning needs lecturers. because this role can guide and assist the information learners get from other sources" (Respondent 08)

The strategy was an assortment of processes that learners implement in the readingabilities text to achieve purpose, information, or knowledge. Furthermore, the academic text examination established the processes for working straight on the actual situation to understand it. CORI lecturers accepted exchange knowledge books to teach. They match text complexity levels to the personal direction. The vocabulary was uncomplicated, and engaging designs support the text are delightful to less-progressive students. CORI combined strategy instruction with motivational features to teach students to learn from texts. The motivational features included presenting primary activities, providing learners with a selection and responsibility, utilizing engaging texts in various genres, giving possibilities concerning collaboration, and managing content purposes through reading instruction. The strategy instruction covered teaching learners to stimulate background information, explore learning in many texts, review and create learning graphically.

\section{DISCUSSION}

Notwithstanding the different views of applying strategies to determine language abilities and system components in the target language, self-learning was vital in Google Classroom language learning. Koc and Koc (2016) asserted that independent learning happens when users design and maintain their learning, encompassing control of their time, ideas, passions, habits, and background. Wahyono (2019) concluded that cognitive strategies were implemented for recognizing and preparing language. It was practical to include selfregulation strategies in task design in technology-intensified online language learning classes.

Google Classroom would be more productive for learners and language lecturers because of its features. Shao et al. (2019) stated that the system streamlined interaction and workflow for learners. Students practice it with efficiency, and lecturers' most essential responsibility was to prepare students to use the apps. This cognitive strategy could be adopted and accepted in classes that utilize Google output attached with hangout, Google mail (Gmail), google drive, YouTube, and others. According to Bayarmaa and Lee (2018), the stream's goals in peer-assisted learning methods and transactional strategies teaching are establishing communications, discussing ideas, or comprehending the flow of assignments, 
material, and exams on the lectures' themes. Vongkrachang and Chinwonno (2015) expressed that Concept-Oriented Reading Instruction was employed with classwork to (pre) test or question, quiz, upload topic, and reflection (washback and feedback). The cognitive strategies concentrate and integrate into uploaded materials on the asynchronous and synchronous classwork bar in Google docs (word), google sheet (excel), Google Slide (PowerPoint), pdf, or audio-video items. The lecturers arrange it to accept several variations in the study, the experience of preconception, and differentiation in learners learning styles in the electronic environment.

The cognitive strategies could be implemented to the uploaded materials in the Google Classroom (Bayarmaa and Lee. 2018). Before the meeting occurs, English lecturers and learners could examine the information's pieces and immediately download the LMS material. Transactional strategies instruction could observe early material when they were omitted. Regarding peer-assisted learning strategies, Havens and Williams (2019) concluded that many language learners followed the activities typed in word directly through their smartphone. They believed that it was more manageable than preparing the laptop and attaching it to the internet connection. Students can know the result of the assignment as a collaborative strategic reading. A lecturer presents a score (grade), and learners could instantly see in their Google Classroom account.

The essential advantage of utilizing Google Classroom is that it is possible to arrange a reading-focused cognitive strategy. Syakur (2020) affirmed that lecturers gave their learners announcements to begin online exchanges or tell them about particular online learning activities in concept-oriented reading instruction. Despite that matter, Liu and Chuang (2016) confirmed that language learners could contribute feedback to their peers by posting during the course discussion in Google Classroom. Therefore, if learners wanted guidance because they have trouble following an assignment or need to know more about the topic, they could get information straigth from their classmates.

\section{CONCLUSION}

Google Classroom conveniently provides electronic language pedagogy environment. Lecturers can apply and adjust the cognitive strategy for their learners. Learners can observe all their quizzes or assignments in a particular folder while lecturers would be able to save learning materials and activities for one term on the cloud system, and every grade can be examined in this application. With the application of transactional strategies and collaborative 
strategic reading, online lecturers (instructors) can exchange information and online sources with their learners immediately. Alternatively, updating e-learning courses, providing links to electronic resources and supplementary e-learning materials, and sending individual emails to each student can also be done in the Google Classroom to serve the learners. This conceptoriented reading enables learners to get up-to-date on current lessons, understand the topics better, and access audio-visual material to improve their e-Learning experience in language pedagogy.

\section{REFERENCES}

Abazi-Bexheti, L., Kadriu, A., Jajaga, E., Apostolova-Trpkovska, M., \& Abazi-Alili, H. (2018). LMS solution: Evidence of Google Classroom usage in higher education. Business Systems Research: International journal of the Society for Advancing Innovation and Research in Economy, 9(1), 31-43.

Adnan, M., \& Anwar, K. (2020). Online Learning amid the COVID-19 Pandemic: Students' Perspectives. Online Submission, 2(1), 45-51.

Ahmadi, D., \& Reza, M. (2018). The use of technology in English language learning: A literature review. International Journal of Research in English Education, 3(2), 115-125.

Ashman, A. F., \& Conway, R. N. (2017). Cognitive strategies for special education: Processbased instruction. Routledge.

Atmojo, A. E. P., \& Nugroho, A. (2020). EFL classes must go online! Teaching activities and challenges during COVID-19 pandemic in Indonesia. Register Journal, 13(1), 49-76.

Azhar, K. A., \& Iqbal, N. (2018). Effectiveness of Google classroom: Teachers' perceptions. Prizren Social Science Journal, 2(2), 52-66.

Bayarmaa, N., \& Lee, K. (2018). A Study on the Application of Google Classroom for Problem-Based Learning. Journal of the Korea Academia-Industrial Cooperation Society, 19(7), 81-87.

Bayarmaa, N., \& Lee, K. (2018). A Study on the Application of Google Classroom for Problem-Based Learning. Journal of the Korea Academia-Industrial Cooperation Society, 19(7), 81-87.

Chapelle, C. A., \& Voss, E. (2016). 20 years of technology and language assessment in language learning \& technology. Language Learning \& Technology, 20(2), 116-128.

Chen, T., Peng, L., Jing, B., Wu, C., Yang, J., \& Cong, G. (2020). The impact of the COVID19 pandemic on user experience with online education platforms in China. Sustainability, 12(18), 7329.

Chinmi, M., Marta, R. F., Haryono, C. G., Fernando, J., \& Goswami, J. K. (2020). EXPLORING ONLINE NEWS AS COMPARATIVE STUDY BETWEEN VENDATU AT INDIAAND RUANGGURU FROM INDONESIA IN COVID-19 PANDEMIC. Call for Papers, 167.

Di Carlo, S. (2017). Understanding cognitive language learning strategies. International Journal of Applied Linguistics and English Literature, 6(2), 114-126.Di Carlo, S. (2017). Understanding cognitive language learning strategies. International Journal of Applied Linguistics and English Literature, 6(2), 114-126. 
Gabriele, L., Marocco, D., Bertacchini, F., Pantano, P., \& Bilotta, E. (2017). An Educational Robotics Lab to Investigate Cognitive Strategies and to Foster Learning in an Arts and Humanities Course Degree. International Journal of Online Engineering, 13(4).

Gilakjani, A. P. (2017). A review of the literature on the integration of technology into the learning and teaching of English language skills. International Journal of English Linguistics, 7(5), 95-106.

Gilakjani, A. P., \& Sabouri, N. B. (2016). Learners' Listening Comprehension Difficulties in English Language Learning: A Literature Review. English language teaching, 9(6), 123 133.

Havens, P. S., \& Williams, M. S. (2019). University Peer-Assisted Learning Strategies in the Humanities. Journal of College Reading and Learning, 49(3), 160-169.

Izenstark, A., \& Leahy, K. L. (2015). Google classroom for librarians: features and opportunities. Library Hi Tech News.

Kashefian-Naeeini, S., \& Maarof, N. (2016). A study of the use of language learning strategies among students in Iran. Malaysian Journal of ELT research, 6(1), 39.

Koc, D. K., \& Koc, S. E. (2016). Understanding learner autonomy through cognitive, metacognitive and social strategies used by English language learners in a computerbased classroom. Journal of Language Teaching and Learning, 6(2), 58-69.

Kumar, J. A., Bervell, B., \& Osman, S. (2020). Google classroom: insights from Malaysian higher education students' and instructors' experiences. Education and information technologies, 25(5), 4175-4195.

Lai, C. (2015). Modeling teachers' influence on learners' self-directed use of technology for language learning outside the classroom. Computers \& Education, 82, 74-83.

Liu, H. C., \& Chuang, H. H. (2016). Integrating Google Classroom to Teach Writing in Taiwan. Minnesota Summit on Learning \& Technology.

Qazi, A., Naseer, K., Qazi, J., AlSalman, H., Naseem, U., Yang, S., ... \& Gumaei, A. (2020). Conventional to online education during COVID-19 pandemic: Do develop and underdeveloped nations cope alike. Children and Youth Services Review, 119, 105582.

Regan, K., Evmenova, A. S., Sacco, D., Schwartzer, J., Chirinos, D. S., \& Hughes, M. D. (2019). Teacher perceptions of integrating technology in writing. Technology, Pedagogy and Education, 28(1), 1-19.

Santos, O. C., Saneiro, M., Boticario, J. G., \& Rodriguez-Sanchez, M. C. (2016). Toward interactive context-aware affective educational recommendations in computer-assisted language learning. New Review of Hypermedia and Multimedia, 22(1-2), 27-57.

Shao, K., Pekrun, R., \& Nicholson, L. J. (2019). Emotions in classroom language learning: What can we learn from achievement emotion research?. System, 86, 102121.

Sholah, H. M. (2020). Teaching and Learning English Using Google Classroom for Indonesian Students. Jurnal Pusaka, 8(1), 1-12.

Syakur, A. (2020). The Effectiveness of English Learning Media through Google Classroom in Higher Education. Britain International of Linguistics Arts and Education (BIoLAE) Journal, 2(1), 475-483.

Troussas, C., Chrysafiadi, K., \& Virvou, M. (2019). An intelligent adaptive fuzzy-based inference system for computer-assisted language learning. Expert Systems with Applications, 127, 85-96.

Vongkrachang, S., \& Chinwonno, A. (2015). CORI: Explicit Reading Instruction to Enhance Informational Text Comprehension and Reading Engagement for Thai EFL Students. PASAA: Journal of Language Teaching and Learning in Thailand, 49, 67-104. 
Wahyono, E. (2019). Correlation between students' cognitive reading strategies and reading comprehension. Jurnal Studi Guru dan Pembelajaran, 2(3), 256-263. 